\title{
Assessment of antibody assay methods in determination of prevalence of infectious bursal disease among local chickens and guinea fowls in Kwara state, North Central Nigeria
}

\author{
Oluwafemi Babatunde Daodu ${ }^{1}$, Oladapo Oyedeji Oludairo², Julius Olaniyi Aiyedun², Hauwa Motunrayo Ambali³, \\ Rafiu Adebisi Kadir ${ }^{3}$, Oluwakemi Christiana Daodu ${ }^{4}$, Isaac Dayo Olorunshola ${ }^{1}$ and Arimie Deborah Adah ${ }^{3}$
}

1. Department of Veterinary Microbiology, Faculty of Veterinary Medicine, University of Ilorin, Nigeria, Sub Sahara Africa;

2. Department of Veterinary Public Health and Preventive Medicine, Faculty of Veterinary Medicine, University of Ilorin,

Nigeria, Sub Sahara Africa; 3. Department of Veterinary Medicine, Faculty of Veterinary Medicine, University of Ilorin,

Nigeria, Sub Sahara Africa; 4. Department of Wildlife and Ecotourism, Faculty of Agriculture, University of Ibadan, Nigeria, Sub Sahara Africa.

Corresponding author: Oluwafemi Babatunde Daodu, e-mail: daodu.ob@unilorin.edu.ng; daodu.femi@gmail.com Co-authors: OOO: oludairo@hotmail.com, JOA: olaaiyedun@yahoo.com, HMA: ambali.hm@unilorin.edu.ng,

RAK: kadirrafiu@yahoo.com, OCD: adeniranoc@gmail.com, IDO: idolorunshola@yahoo.com, ADA: adah.ad@unilorin.edu.ng Received: 25-04-2018, Accepted: 13-07-2018, Published online: 28-08-2018

doi: 10.14202/vetworld.2018.1183-1187 How to cite this article: Daodu OB, Oludairo OO, Aiyedun JO, Ambali HM, Kadir RA, Daodu OC, Olorunshola ID, Adah AD (2018) Assessment of antibody assay methods in determination of prevalence of infectious bursal disease among local chickens and guinea fowls in Kwara state, North Central Nigeria, Veterinary World, $11(8): 1183-1187$.

\begin{abstract}
Aim: This study aimed to assess available assay methods for infectious bursal disease (IBD) diagnosis and seromonitoring in local birds. It also sought to know the prevalence of IBD antibodies among local chickens and guinea fowls in Kwara state, North Central Nigeria.

Materials and Methods: Sera were obtained from local chickens and guinea fowls and IBD virus (IBDV) antibodies were assayed using enzyme-linked immunosorbent assay (ELISA), indirect hemagglutination (IHA) test, and agar gel immunodiffusion (AGID) test.

Results: A total of 265 sera were obtained from local birds during dry and wet seasons. ELISA recorded the highest prevalence of $81.1 \%(215 / 265)$ while IHA and AGID detected IBDV antibodies in $183(69.1 \%)$ and 122 (46\%) birds, respectively. Significant differences were established for IBD-positive sera based on the assay method used, bird species, and seasons.

Conclusion: This study indicated that ELISA is the most sensitive and reliable assay method while AGID is the least. It also showed that there is a high prevalence of IBDV antibodies among local birds which were not vaccinated, and this implies a high IBDV activity among these bird species in the study area. This may have significant epidemiological implications on the spread of the virus to exotic bird reared in the rural areas on a commercial scale. Thus, this study suggests continuous surveillance, awareness campaign, and advocacy for vaccination of indigenous birds against IBD.
\end{abstract}

Keywords: agar gel immunodiffusion test, assessment, enzyme-linked immunosorbent assay, indirect hemagglutination test, infectious bursal disease, Kwara state, prevalence.

\section{Introduction}

Infectious bursal disease (Gumboro, IBD) was first observed in the area of Gumboro, in Delaware, USA [1]. The virus belongs to the family Birnaviridae, genus Avibirnavirus. It possesses two molecules of linear double-stranded RNA of approximately $6 \mathrm{kbp}$ size [2]. It is a hardy virus and can survive under harsh environmental condition or treatment [3]. Gumboro virus is extremely contagious and causes a self-limiting disease in both domestic birds (chickens and turkeys) and wild birds (guinea fowl, quail, ducks, and pheasants) [4].

Copyright: Daodu, et al. Open Access. This article is distributed under the terms of the Creative Commons Attribution 4.0 International License (http://creativecommons.org/licenses/by/4.0/), which permits unrestricted use, distribution, and reproduction in any medium, provided you give appropriate credit to the original author(s) and the source, provide a link to the Creative Commons license, and indicate if changes were made. The Creative Commons Public Domain Dedication waiver (http://creativecommons.org/ publicdomain/zero/1.0/) applies to the data made available in this article, unless otherwise stated.
The contribution of village-reared poultry to meat production in Nigeria cannot be overemphasized. Chickens are the most important poultry species reared [5]. Apart from non-infectious diseases limiting poultry production, Gumboro disease is classified as the first infectious diseases affecting them [1]. Although commercial vaccines are available for prevention against IBD virus (IBDV) and some other infectious viral diseases, domesticated birds in villages in Nigeria are rarely vaccinated [6-8]. This might be based on overwhelming factors such as ignorance of vaccination, cost, availability of veterinarians, or licensed vaccinators to mention a few.

Several diagnostic techniques have been used in the detection of IBDV antigen, antibodies, and conserved genes. Serological assays which have been in use for diagnosis and/or confirmation of Gumboro disease include agar gel immunodiffusion test (AGID), indirect hemagglutination (IHA) test, passive hemagglutination test, enzyme-linked immunosorbent assay 
(ELISA), immunohistopathology test, immunoperoxidase test, counterimmunoelectrophoresis test, and immunofluorescent test. These have variable sensitivity and specificity [8-15].

Majority of the owners of these village birds are low-income earners who cannot afford the running cost of some of these techniques. Despite the severity and economic loss associated with Gumboro disease, there has not been any report of the disease in Kwara state, especially among local birds. To this end, this study aimed to detect IBDV antibody using three available serodiagnostic assays which are rapid, cheap, and accessible to the local bird keepers and to compare the sensitivity of the diagnostic assays. It also aimed to determine the prevalence of IBDV antibodies in local birds in Kwara State.

\section{Materials and Methods}

\section{Ethical approval}

All applicable international, national, and/or institutional guidelines for the care and use of animals were duly followed.

\section{Study area and sample collection}

The study area was Oja-titun poultry abattoir (market) located in Ilorin metropolis, North Central Nigeria. It is a major abattoir that receives the highest number of local birds in Kwara state for sale and/or slaughter. Birds usually originate from villages within the state and neighboring states.

Immediately after slaughter, blood samples were collected from chickens and guinea fowls into sterile plain bottles and were transported to the laboratory under a cold chain. The blood was then centrifuged at $2500 \mathrm{rpm}$ for $10 \mathrm{~min}$ to harvest the serum into a sterile Cryovial tube. Separated sera were stored at $-20^{\circ} \mathrm{C}$ until the time of use for assay. Sampling was seasonally based and other variables such as bird species and category were recorded.

\section{Assay methods}

Each of the sera was differently assayed using AGID test, IHA test, and ELISA. The results were entered into a spreadsheet for analyses.

\section{IBD antigen preparation}

The bursa of Fabricius of IBDV-infected chickens was harvested and processed for virus isolation. The isolate from processed tissue was identified as IBDV using IBDV-specific hyperimmune serum [8]. The sera collected from birds and prepared viral antigen were put to use in AGID and IHA assays.

\section{AGID test}

Immunodiffusion plates were prepared by dissolving $8 \mathrm{~g}$ sodium chloride in $100 \mathrm{ml}$ of distilled water followed by the addition of $1.25 \mathrm{~g}$ agar noble. This mixture was gently mixed and boiled in a water bath until the agar is completely dissolved. The agar was allowed to cool to about $50^{\circ} \mathrm{C}$ before it was poured in 6 of $9 \mathrm{~cm}$ immunodiffusion plates and allowed to solidify. The plates were then kept overnight at $4^{\circ} \mathrm{C}$ before used. Using a template and well cutter $(4 \mathrm{~mm})$, seven wells of $4 \mathrm{~mm}$ (a group of six wells surrounding a center well) were made. The surrounding wells were filled with test sera while the center well was filled with IBDV antigen, and this was recorded in the template sheet. Positive and negative controls (PCX and NCX) were also included to validate the result using known IBDV-positive antigen, positive serum, and negative serum. The plates were incubated in a humid chamber for up to $35 \mathrm{~h}$ and read using a diffused light and recorded as positive or negative based on the presence or absence of white precipitation line, respectively, between serum and antigen wells.

\section{IHA test}

\section{Erythrocytes sensitization}

Human blood group O was collected into a sterile anticoagulant tube using a sterile hypodermic syringe under sterile condition. The blood was then centrifuged at $3000 \mathrm{rpm}$ for $10 \mathrm{~min}$ and the supernatant with white blood cell layer removed and discarded. The red blood cells were then washed 3 times using phosphate buffer saline (PBS) with the removal of supernatant at each wash.

Subsequently, one volume each of washed red blood cell (RBC) and prepared IBDV antigen was mixed, and two volume of PBS was the added. The mixture was gently shaken and incubated at $37^{\circ} \mathrm{C}$ for $45 \mathrm{~min}$. To ensure adequate antigen-RBC contact, the mixture was shaken at intervals during incubation. Unattached antigens were later removed from the mixture by centrifugation at $3000 \mathrm{rpm}$ for $10 \mathrm{~min}$ after which the supernatant was discarded. To ensure total removal of unbounded antigen, washing was repeated using PBS, thereby leaving behind sensitized RBC (IBDV antigen-human RBC O blood group complex).

Slide agglutination test was used to confirm the sensitization of human erythrocytes.

\section{Hemagglutination test}

The test sera were heat inactivated in a water bath at $56^{\circ} \mathrm{C}$ for 30 min while $1 \%$ sensitized erythrocytes were prepared. The IHA test was carried out as described by Hussain et al. [9]. Briefly, $50 \mu 1$ of PBS was dispensed into all the wells of "U"-shaped bottom microtiter plate. Then, $50 \mu 1$ of test serum was then dispensed in the first well of the row followed by 2 -fold dilution, and subsequently, $50 \mu \mathrm{l}$ of the mixture from the $12^{\text {th }}$ well was discarded. After this, $50 \mu 1$ of $1 \%$ sensitized RBC was added to all the wells. PCX and NCXs were included in the test. The microtiter plate was then tapped to ensure adequate surface antibody and sensitized RBC contact. The plate was incubated at $37^{\circ} \mathrm{C}$ for $30 \mathrm{~min}$. Sera samples showing characteristic tent formation/reticulum settling of erythrocytes at the bottom of the microtiter plate were regarded as positive while those with central button-shaped settling of erythrocytes were regarded as negative. The IHA titer results were recorded. 
ELISA

The presence of IBDV antibody was assayed using ELISA kit (IDEXX ${ }^{\circledR}$ Laboratory, Inc., United States). The manufacturer's instructions were adhered to strictly. Briefly, the protocol involved 1:500 dilution of sera sample using deionized water. $100 \mu \mathrm{l}$ each of undiluted negative and positive controls was dispensed in duplicate wells of an antigen-coated microtiter plate. Then, $100 \mu \mathrm{l}$ of diluted sera sample was dispensed into appropriate well. The plate was left to incubate for $30 \mathrm{~min}$ at room temperature $\left(18-26^{\circ} \mathrm{C}\right)$. The solution in the wells was then removed, and each well was washed with approximately $350 \mu$ l of deionized water 3-5 times and then tapped on a paper towel to remove any residual wash fluid. This was followed by the addition of $100 \mu \mathrm{l}$ of conjugate into each well. The plate was allowed for incubation for 30 minutes at room temperature. Removal and washing of the wells were repeated as described previously, then $100 \mu \mathrm{l}$ of TMB substrate was dispensed into each well, and the plate was left to incubate at room temperature for 15 min. Finally, $100 \mu$ l of stop solution was added to each of the wells. The absorbance value was measured at $650 \mathrm{~nm}$ using ELISA reader. The result was validated based on the manufacturer's recommendation that mean OD value of NCX must be $\leq 0.150$, and when it is subtracted from mean OD of PCX, the result must be $>0.075$.

The endpoint titer of the samples was calculated using the formula $\log _{10}$ Titer $=1.09\left(\log _{10} \mathrm{~S} / \mathrm{P}\right)+\mathrm{C}$.

Where, $\mathrm{S} / \mathrm{P}$ (sample to positive ratio $)=($ Sample mean-NCX)/(PCX-NCX) and $\mathrm{C}$ is 3.36 (relates $\mathrm{S} / \mathrm{P}$ at a 1:500 dilution to an endpoint titer). The presence of IBD antibody was reported as positive when $\mathrm{S} / \mathrm{P}$ ratio is $>0.2$ and negative when $\mathrm{S} / \mathrm{P}$ ratio is $\leq 0.2$. Furthermore, the antilogarithm of Log10 titer was calculated (IDEXX ${ }^{\circledR}$ software) and recorded as the quantity of IBD antibody in each sample.

\section{Statistical analysis}

Data were entered into GraphPad Prism version 5.03 (GraphPad Software Inc., USA) to test for significant differences in the assay methods used for detection of IBDV antibody. The statistical significance of bird species, seasons, and age group was also determined on nominal (positive or negative) and titer results using Fisher's exact or Chi-square test and Student's t-test (unpaired) or one-way ANOVA, respectively. Confidence interval at 95\% (CI 95\%) and odds ratio (OR) was also calculated. Statistical significance was assumed at $\mathrm{p}<0.05$.

\section{Results}

The number of IBDV-positive sera varied depending on assay used. ELISA detected IBDV antibody in $215(81.1 \%)$ sera while IHA and AGID detected $183(69.1 \%)$ and 122 (46\%) IBD-positive sera, respectively (Table-1). The result also showed a significant difference in the sensitivity of various tests (AGID, IHA, and ELISA) in the detection of IBDV antibody with $\mathrm{p}<0.0001\left(\chi^{2}=74.46 ; \mathrm{df}=8\right)$. IHA titer ranged from $1: 2$ to $1: 256$ with geometric mean titer and modal titer of 3.1 and $1: 16$, respectively (Table-2).

Due to the high sensitivity and specificity of ELISA compared with the other two tests, more insight was obtained for important variables obtained during sample collection. Among the birds, 85.8\% $(211 / 246)$ of chicken and $21.1 \%(4 / 19)$ of guinea fowl had IBDV antibody (Table-3). During dry season, $86.5 \%$ (147/170) positive sera were obtained which was higher compared to wet season samples (Table-3). Furthermore, there was a significant difference in the exposure of chickens and guinea fowls to IBDV as determined by antibody detection $(\mathrm{p}<0.0001$; $\mathrm{OR}=0.04423$; CI $95 \%=0.01387-0.1411$ ) (Table-3). However, the difference in their IBDV antibody titers remained non-significant $(\mathrm{p}=0.2729$ CI 95\% $=-567.8$ 2019) (Table 4). Significant difference was recorded for seasonal mean IBDV antibody titer ( $\mathrm{p}=0.043$; CI $95 \%=-815.0--15.71)($ Table-4) and seasonal exposure $(\mathrm{p}=0.005 ; \mathrm{OR}=0.3941 ; \mathrm{CI} 95 \%=0.2107-0.7371)$ (Table-3). This result indicated that birds were more exposed 0.3941 times during dry season compared to the wet season. There was no significant difference in the presence of IBDV antibody and its mean titers with regard to bird category (hen, cock, and grower).

\section{Discussion}

The study showed that ELISA recorded the highest prevalence of $81.1 \%(215 / 265)$ for IBDV antibody while IHA and AGID detected IBDV antibody in $183(69.1 \%)$ and $122(46 \%)$ sera samples, respectively. This indicated that local birds in the study area were exposed to the wild-type IBDV since they were not vaccinated. Furthermore, various techniques used indicated that ELISA is most sensitive, followed by IHA while AGID was the least sensitive assay for IBDV antibody detection. This high IBDV antibody prevalence in Ilorin, North Central Nigeria, recorded in this study is in agreement with Okwor et al. [8], Adene et al. [16], Lawal et al. [17], and Sule et al. [18], who

Table-1: Comparison of AGPT, IHT, and ELISA results for detection of infectious bursal disease in local chickens and guinea fowls.

\begin{tabular}{lcccc}
\hline Diagnostic test & Number of sera sample & Positive sera (\%) & Negative sera (\%) & p-value \\
\hline AGID & 265 & $122(46.0)$ & $143(54.0)$ & $<0.0001\left(\chi^{2}=74.46 ; \mathrm{df}=8\right)$ \\
IHA & 265 & $183(69.1)$ & $82(30.9)$ & \\
ELISA & 265 & $215(81.1)$ & $50(18.9)$ & \\
\hline
\end{tabular}

AGID=Agar gel immunodiffusion test, IHA=Indirect hemagglutination test, ELISA=Enzyme-linked immunosorbent assay

Veterinary World, EISSN: 2231-0916 
reported the prevalence of $88.4 \%, 68.0 \%, 63.5 \%$, and $63 \%$, respectively, in South-eastern, North-eastern, and South-western region of Nigeria. The slight variations in IBDV antibody prevalence in various regions of Nigeria as reported by various researchers also suggest that environmental factors (especially weather and vegetation) might influence the spread of the virus [19]. In addition, differences in the prevalence of IBDV antibody observed using ELISA, IHA, and AGID in this study may be the reason for variation in prevalence rates in different regions in Nigeria since researchers used different assays. In general, ELISA has been described to be the most sensitive and specific antibody assay, followed by IHA. The least sensitive is AGID [8]. In comparison to AGID and ELISA, IHA become more useful when it is necessary to determine the antibody titer (though serum titration can be done to estimate the antibody titer). The study showed that there was a significant difference in the sensitivity among the three IBDV antibody detection techniques used $\left(\mathrm{p}<0.0001, \chi^{2}=74.46 ; \mathrm{df}=8\right)$. Using ELISA, the prevalence of IBDV antibody in local

Table-2: IHA titer for infectious bursal disease in local chickens and guinea fowls.

\begin{tabular}{lcccccccc}
\hline Positive sera \\
\hline IHA titer & $1: 2$ & $1: 4$ & $1: 8$ & $1: 16$ & $1: 32$ & $1: 64$ & $1: 128$ & $1: 256$ \\
Number of & 20 & 30 & 44 & 32 & 30 & 15 & 3 & 9 \\
samples & & & & & & & & \\
GMT & 3.1 & & & & & & & \\
\hline
\end{tabular}

IHA=Indirect hemagglutination chicken was $85.8 \%(222 / 246)$ compared to guinea fowl $21.1 \%(4 / 19)$. This was statistically significant $(\mathrm{p}<0.0001 ; \mathrm{OR}=0.04423$; CI 95\% $=0.01387-0.1411)$. This suggests that chickens might be at more risk and susceptible to wild-type IBDV, leading to a higher seroconversion rate than shown in guinea fowl.

The study further showed a significant difference in seasonal prevalence of IBDV antibody with $86.5 \%$ and $71.6 \%$ in dry and wet season, respectively. This indicated that local birds were more exposed during dry season, a period when there is intense scavenging of scarce food in the environment. This has also been observed for some viral diseases in extensively managed poultry [19]. The difference in the prevalence due to season was found to be significant ( $\mathrm{p}=0.005$; $\mathrm{OR}=0.3941$; CI $95 \%=0.2107-0.7371)$, and it indicated that birds were more exposed 0.3941 times during dry season compared to wet season. This result is in discordant with Lawal et al. [17] who reported a higher prevalence in wet season than in dry season. This difference might be as a result of climatic and vegetation differences which has been reported to influence disease transmission in poultry [19].

\section{Conclusion}

This study was able to show that of the three different accessible and cheap serodiagnostic assays available to the local bird keepers, ELISA is the most sensitive and reliable while AGID is the least sensitive. It also showed that there is a high prevalence of IBDV antibodies among local birds in the study area.

Table-3: Distribution and significance of IBDV antibody-positive birds using ELISA.

\begin{tabular}{lcccc}
\hline Features & Number of sera & Number of positive sera (\%) & $*$ p-value & $*$ OR (*CI 95\%) \\
\hline $\begin{array}{l}\text { Bird species } \\
\text { Chicken }\end{array}$ & 246 & $211(85.8)$ & $<0.0001$ & $0.04423(0.01387-0.1411)$ \\
$\quad$ Guinea fowl & 19 & $4(21.1)$ & & \\
Season & 170 & $147(86.5)$ & 0.005 & $0.3941(0.2107-0.7371)$ \\
$\quad$ Dry & 95 & $68(71.6)$ & & \\
$\quad$ Wet & 39 & $29(74.4)$ & $0.2062\left(\chi^{2}=3.158 ; d f=2\right)$ & \\
Bird categories & 21 & $15(71.4)$ & & \\
Hen & 205 & $171(83.4)$ & & \\
Cock & & & & \\
Grower & & & & \\
\hline
\end{tabular}

*Inferential statistic based on positive and negative result. OR=Odds ratio, CI 95\%=Confidence interval $95 \%$, ELISA=Enzyme-linked immunosorbent assay, IBDV=Infectious bursal disease virus

Table-4: IBDV antibody titer distribution in local chickens and Guinea fowls using ELISA.

\begin{tabular}{lccc}
\hline Features & Number of positive sera (\%) & a Mean \pm SEM & 'p-value (CI) \\
\hline $\begin{array}{l}\text { Bird species } \\
\text { Chicken }\end{array}$ & $211(85.8)$ & $2232 \pm 94.58$ & $0.2729(-567.8-2019)$ \\
$\quad$ Guinea fowl & $4(21.1)$ & $1507 \pm 487.5$ & \\
Season & $147(86.5)$ & $2097 \pm 111.4$ & $0.0430(-815.0-15.71)$ \\
$\quad$ Dry & $68(71.6)$ & $2512 \pm 166.0$ & 0.2855 \\
$\quad$ Wet & $29(74.4)$ & $2486 \pm 245.8$ & \\
Bird categories & $15(71.4)$ & $1830 \pm 303.4$ & \\
$\quad$ Hen & $171(83.4)$ & $2206 \pm 106.5$ & \\
Cock & &
\end{tabular}

${ }^{a}$ Antilog10 titer. ${ }^{b}$ Significance calculated using the sample titers. CI 95\%=Confidence interval 95\%, ELISA=Enzyme-linked immunosorbent assay, IBDV=Infectious bursal disease virus, SEM=Standard error of the mean 
There were significant differences found based on seasons and bird species. The high prevalence recorded in this study indicated a high IBDV activity among the bird species, and this may have significant epidemiological implications on the spread of the virus to exotic birds reared in the rural areas on a commercial scale. Continuous surveillance, awareness campaign, and advocacy for vaccination should be encouraged, especially among the local bird keepers.

\section{Authors' Contributions}

OBD and OCD conceived, designed, and collected sample for the research study. OBD, OOO, JOA and HMA, RAK, and ADA carried out the laboratory assays. OBD, OCD, IDO, and ADA analyzed data and drafted manuscript. All authors read, revised, and approved the final manuscript.

\section{Acknowledgments}

The authors want to appreciate the immediate past Director of the Veterinary Teaching Hospital of the University of Ilorin, Prof. E.O. Oyedipe who permitted us to carry out part of this research in the microbiology laboratory. We are also grateful for the support offered by the laboratory technologist Mr. Shafi A.A. The authors did not receive any fund for this study.

\section{Competing Interests} interests.

The authors declare that they have no competing

\section{References}

1. Khan, R.S.A., Sajid, S., Habib, M., Ali, W., Shah, M.S. and Sarfraz, M. (2017) History of gumboro (infectious bursal disease) in Pakistan. Saudi Pharm. J., 25(4): 453-459.

2. Ferrero, D., Garriga, D., Navarro, A., Rodríguez, J.F. and Verdaguer, N. (2015) Infectious bursal disease virus VP3 upregulates VP1-mediated RNA-dependent RNA replication. J. Virol., 89: 11165-11168.

3. Mac Lachlan, N. and Dubovi, J. (2011) Fenner's Veterinary Virology. $4^{\text {th }}$ ed. Elsevier Inc., Oxford. p293-298.

4. Anon. (2018) Available from: http://www.waddl.vetmed. wsu.edu/animal-disease-faq/infectious-bursal-disease. Accessed on 09-04-2018.

5. Acamovic, T., Sinurat, A., Natarajan, A., Anitha, K., Chandrasekaran, D., Shindey, D., Sparks, N., Oduguwa, O., Mupeta, B. and Kitalyi, A. (2005) Poultry. In: Owen, E., Kitalyi, A., Jayasuriya, N. and Smith, T., editors. Livestock and Wealth Creation: Improving the Husbandry of Animals Kept by Resource-Poor People in Developing Countries. Nottingham University Press, Nottingham. p301-322.

6. Lawal, J.R., Jajere, S.M., Mustapha, M., Bello, A.M., Wakil, Y., Geidam, Y.A., Ibrahim, U.I. and Gulani, I.A. (2015) Prevalence of Newcastle disease in Gombe,
Northeastern Nigeria: A Ten-Year Retrospective Study (2004-2013). Br. Microbiol. Res. J., 6(6): 367-375.

7. Lawal, J.R., El-Yuguda, A.D. and Ibrahim, U.I. (2016) Survey on prevalence of Newcastle disease antibodies in village poultry at live birds markets in Gombe, Nigeria. J. Anim. Sci. Livest. Prod., 1(1): 1.

8. Okwor, E.C., Eze, D.C., Okonkwo, K.E. and Ibu, J.O. (2011) Comparative evaluation of agar gel precipitation test (AGPT) and indirect haemagglutination test (IHA) for the detection of antibodies against infectious bursal disease (IBD) virus in village chickens. Afr. J. Biotech., 10(71): 16024-16027.

9. Hussain, I., Zahoo, M.A., Rasool, M.H., ShahidMahmood, M.M., Mansoor, M.K. and Riaz, M.N. (2003) Detection of Serum antibody levels against Infectious bursal disease (IBD) virus using indirect haemagglutination (IH) test in commercial broilers. Int. J. Poult. Sci., 2(6): 442-445.

10. Allan, G.M., Mc Nulty, M.S., Connor, T.J., McCracken, R.M. and Mc Ferran, J.B. (1984) Rapid diagnosis of infectious bursal disease infection by immunofluorescence on clinical materials. Avian Pathol., 13: 419-427.

11. Durojaiye, O.A., Adene, D.F. and Owoade, A.A. (1985) Counter immune electrophoresis in the diagnosis of infectious bursal disease of poultry. Trop. Anim. Health Prod., 17: 225-229.

12. Castello, L., Martinez, B.L. and Heronodez, K. (1987) Comparison of the agar gel precipitation, virus neutralization and enzyme-linked immunosorbent assay in the determination of antibodies to infectious bursal disease virus. Vet-Mexico, 18: 317-323.

13. Aliev, A.S., Dzhavadov, E.D. and Leont'eva, M.M. (1990) Indirect haemagglutination test for infectious bursal disease of fowls. Vet. Bull., 60: 47-67.

14. Nachimuthu, K., Rai, G.D., Thangavelu, A. and Venkatesan, R.A. (1995) Reverse passive haemagglutination test in the diagnosis of infectious bursal disease. Trop. Anim. Health Prod., 27: 43-46.

15. Oluwayelu, D.O., Adebiyi, A.I., Olaniyan, I., Ezewele, P. and Aina, O. (2014) Occurrence of Newcastle disease and infectious bursal disease virus antibodies in double-spurred francolins in Nigeria. J. Vet. Med., 2014: 106898.

16. Adene, D.F., Oyejide, A. and Owoade, A.A. (1985) Studies on the possible roles of naturally infected local chickens and vaccine virus in the epidemiology of infectious bursal disease. Rev. Elevage Med. Vet. Pays Trop., 38: 122-126.

17. Lawal, J.R., Jajere, S.M., Bello, A.M., Mustapha, M., Wakil, Y., Ndahi, J.J., Mustapha, F.B., Paul, B.T., Gulano, I.A., Ibrahim, U.I, Geidam, Y.A., Ambali, A.G. and Waziri, I. (2014) Prevalence of infectious bursal disease (Gumboro) antibodies in village chickens in Gombe State, Northeastern Nigeria. Int. J. Poult. Sci., 13(12): 703-708.

18. Sule, A.G., Umoh, J.U., Abdu, P.A., Ajogi, J., Jibrin, U.M., Tijjani, A.O., Atsanda, N.N. and Gidado, A.S. (2013) A serological survey for infectious bursal disease virus antibodies among village chickens in Yobe State, Nigeria. Int. J. Agric. Sci., 3(7): 596-598.

19. Abdu, P.A., Mera, U.M. and Sa'idu, L. (1992) A Study of Chicken Mortality in Zaria, Nigeria, In: Proceeding of National Workshop on livestock and Veterinary Services, Held at National Veterinary research institute, Vom, on 11-14 August 1992. p51-55. 